\title{
IMPLEMENTASI \\ PERATURAN GUBERNUR ACEH NOMOR 5 TAHUN 2018 \\ DI KABUPATEN ACEH TIMUR
}

\author{
IMPLEMENTATION \\ REGULATION OF THE GOVERNOR OF ACEH NUMBER 5 OF 2018 \\ IN EAST ACEH DISTRICT
}

Fajar Adi Putra

\author{
Mahasiswa Jurusan Hukum Tata Negara \\ Program Magister Hukum, Universitas Malikusaleh \\ Email : fajaradi.putra66@gmail.com
}

\begin{abstract}
Aceh is a province in Indonesia that applies Islamic law in law enforcement, not infrequently in law enforcement in East Aceh District by prosecutors experiencing obstacles in applying Aceh Governor Regulation No. 5 of 2018 for the perpetrators of Jarimah, so that the implementation up to now the Prosecutor is guided by the Aceh Qanun Number 7 of 2013 concerning Jinayat Procedural Law. This study aims to find out how the implementation of the Aceh Governor's Regulation No. 5 of 2018 by the Prosecutors in East Aceh District and why the implementation of the Aceh Governor's Regulation is experiencing obstacles. This study uses an empirical juridical approach to the research location in Lapi Class II B Idi, as well as using secondary data and primary data, then collecting data from literature, interviews and observations, and from the results of these data the data are arranged in a descriptive analysis. The conclusion of this study is that Aceh's Governor Regulation Number 5 Year 2018 cannot be implemented in Idi Class II B Prison, so that in carrying out the Prosecutor's whip uqubat based on Article 262 Aceh Qanun Number 7 of 2013, this is due to obstacles encountered by the Prosecutor in implement the Governor Regulation Number 5 of 2018, including the absence of facilities and infrastructure in Class II B Idi prison, the absence of Technical Instructions and Implementing Guidelines related to the implementation of Governor Regulation Number 5 of 2018 from the Aceh High Prosecutor Office and Class II B Idi Prison, the budget which is limited from the local government, will cause a commotion between prisoners, and the community does not know the whip, given the spirit of the whip is to give the effect of shame on the perpetrators and provide lessons for the community.
\end{abstract}

Keywords: Governor Regulation, Jinayat Procedure Law, Aceh. 


\section{Intisari}

Aceh merupakan Provinsi di Indonesia yang menerapkan Hukum Islam dalam penegakan hukum, tidak jarang dalam penegakan hukum di Kabupaten Aceh Timur oleh Jaksa mengalami hambatan dalam menerapkan Peraturan Gubernur Aceh Nomor 5 Tahun 2018 bagi pelaku jarimah, sehingga pelaksanannya hingga saat ini Jaksa berpedoman kepada Qanun Aceh Nomor 7 Tahun 2013 Tentang Hukum Acara Jinayat. Penelitian ini bertujuan untuk mengetahui bagaimana pelaksanaan Peraturan Gubernur Aceh Nomor 5 Tahun 2018 oleh Jaksa di Kabupaten Aceh Timur dan mengapa pelaksanaan Peraturan Gubernur Aceh tersebut mengalami hambatan. Penelitian ini menggunakan pendekatan yuridis empiris dengan lokasi penelitian di Lapas Kelas II B Idi, serta menggunakan data sekunder dan data primer, kemudian dilakukan pengumpulan data secara kepustakaan, wawancara dan observasi, dan dari hasil data tersebut data disusun secara deskritif analisis. Kesimpulan dari penelitian ini yaitu bahwa Peraturan Gubernur Aceh Nomor 5 Tahun 2018 tidak dapat dilaksanakan di dalam Lapas Kelas II B Idi, sehingga dalam melaksanakan uqubat cambuk Jaksa berpedoman pada Pasal 262 Qanun Aceh Nomor 7 Tahun 2013, hal ini dikarenakan terjadi hambatan yang ditemui Jaksa dalam melaksanakan Peraturan Gubernur Nomor 5 tahun 2018 tersebut, antara lain tidak adanya sarana dan prasarana di lapas Kelas II B Idi, belum adanya Petunjuk Teknis dan Petunjuk Pelaksana terkait pelaksanaan Peraturan Gubernur Nomor 5 tahun 2018 dari Kejaksaan Tinggi Aceh maupun Lapas Kelas II B Idi, anggaran yang terbatas dari Pemerintah daerah, akan menimbulkan keributan antar narapidana, dan masyarakat tidak mengetahui cambuk tersebut, mengingat ruh dari cambuk adalah memberikan efek malu terhadap pelaku serta memberikan pelajaran bagi masyarakat.

Kata Kunci : Peraturan Gubernur, Hukum Acara Jinayat, Aceh.

\section{A. Latar Belakang Masalah}

Provinsi Aceh merupakan salah satu Provinsi di Indonesia yang diberikan keistimewaan dari provinsi lainnya yaitu dengan diberlakukannya ketentuan mengenai penerapan pelaksanaan Syari'at Islam sebagaimana dimuat didalam UU RI Nomor 44 Tahun 1999 tentang Penyelenggaraan Keistimewaan Daerah Istimewa Aceh, UU RI Nomor 18 Tahun 2001 tentang Otonomi Khusus Provinsi Daerah Istimewa Aceh Sebagai Provinsi Nanggroe Aceh Darussalam, dan dalam hal pelaksanaan sistem pemerintahan diatur secara khusus dalam UU RI Nomor 11 Tahun 2006 tentang Pemerintahan Aceh.

Upaya penegakan hukum dan pelaksanan syari'at Islam di Provinsi Aceh diantaranya adalah pelaksanaan syari'at Islam sebagai hukum positif yang berlaku di Aceh atau dikenal dengan Qanun Aceh. Qanun Aceh sendiri berfungsi untuk melaksanakan sebuah undang-undang dibidang syari'at Islam atau Pidana 
Islam tanpa harus melalui Peraturan Pemerintah (PP), ${ }^{1}$ sehingga untuk melaksanakan syari'at Islam Pemerintah Aceh melalui Dewan Pertimbangan Rakyat Aceh (DPRA) bersama Gubernur membuat Qanun Aceh Nomor 7 Tahun 2013 tentang Hukum Acara Jinayat dan Qanun Aceh Nomor 6 Tahun 2014 Tentang Hukum Jinayat yang telah mencabut Qanun sebelumnya sehingga tidak berlaku lagi yaitu Qanun Aceh Nomor 12 Tahun 2003 Tentang Khamar, Qanun Aceh Nomor 13 Tahun 2003 Tentang Maisir (Perjudian), dan Qanun Aceh Nomor 14 Tahun 2003 Tentang Khalwat (Mesum).

Guna melaksanakan dan menegakan hukum tersebut, maka perlu adanya eksistensi lembaga penegakan hukum diantaranya yaitu Kejaksaan Agung Republik Indonesia. Konsep dasar eksistensi lembaga penegakan hukum adalah kewenangan yang melekat untuk berbuat dan bertindak, sehinga tindakan dilaksanakan atas dasar kewenangan yang diatur dalam hukum (rechtsmatigheid), dan berpijak pada asas specialitas (specialiteitbeginselen) hakikatnya dalam menjalankan wewenangnya lembaga penegak hukum harus berorientasi pada tujuan diberikannya wewenang. ${ }^{2}$

Kejaksaan Negeri Aceh Timur merupakan salah satu Kejaksaan Negeri yang berbeda dari Kejaksaan Negeri lainnya yang berada di luar Provinsi Aceh. Hal ini terlihat dari penanganan perkara yang ada di Aceh yang memiliki aturan hukumnya sendiri yang diberikan secara khusus mengenai pelaksanaan Syari'at Islam sebagaimana bunyi Pasal 3 Ayat (2) UU RI Nomor 44 Tahun 1999 tentang Penyelenggaraan Keistimewaan Provinsi Aceh yaitu penyelenggaraan kehidupan beragama, penyelenggaraan kehidupan adat, penyelenggaraan pendidikan, dan peran ulama dalam penetapan kebijakan daerah, serta UU RI Nomor 11 tahun 2006 tentang Pemerintahan Aceh, maka secara yuridis Syari'at Islam tersebut menjadi Hukum Positif (hukum yang berlaku) di masyarakat Aceh.

Berdasarkan kepada kedua peraturan tersebut, maka terhadap beberapa ketentuan hukum maupun ketentuan perundangan dapat dikesampingkan selama jika terhadap permasalahan tersebut diatur didalam Qanun. Sebagaimana diketahui bahwa menurut Soerjono Soekanto hukum setidaknya mempunyai tiga peranan utama dalam masyarakat yaitu pertama, sebagai sarana pengendalian sosial, kedua, sebagai sarana untuk memperlancar proses interaksi sosial, ketiga, sebagai sarana untuk menciptakan keadaan tertentu. ${ }^{3}$

Adanya keistimewaan tersebut dengan sendirinya telah memberikan kewenangan kepada lembaga eksekutif, legislatif maupun yudikatif di Provinsi Aceh untuk menyusun beberapa kebijakan ataupun peraturan yang ditujukan sebagai dasar pelaksanaan Syariat Islam secara menyeluruh (Kaffah), inilah yang menjadi landasan Pemerintah Aceh atau Gubernur Aceh pada saat itu Irwandi Yusuf mengeluarkan Peraturan Gubernur Aceh atau dikenal dengan nama Pergub Aceh Nomor 5 Tahun 2018 tentang pelaksanaan Hukum Acara Jinayat pada

\footnotetext{
${ }^{1}$ Abdul Gani Isa, Formalisasi Syari'at Islam di Aceh (Pendekatan Adat, Budaya, dan Hukum), Aceh: Yayasan Pena Banda Aceh, Cet-I, 2013, hlm.355.

2 Sadjijono, Hukum Antara Sollen dan Sein Dalam Perspektif Praktek Hukum di Indonesia, Surabaya: Ubhara Press dan Laksbang Pressindo, 2017, Cet ke- II, hlm. 48.

${ }^{3}$ Riduan Syarani, Rangkuman Instisari Ilmu Hukum, Bandung: Citra Aditya Bakti, 2004, hlm. 7.
}

Suloh: Jurnal Fakultas Hukum Universitas Malikussaleh, Vol. 9, No. 1, April 2021, pp. 27 - 28 
tanggal 28 Februari 2018 yang pada intinya menjelaskan tentang pelaksanaan lokasi dilakukannya Uqubat Cambuk.

Peraturan Gubernur Nomor 5 Tahun 2018 Tentang pelaksanaan Hukum Acara Jinayat tersebut merupakan aturan delegasi (delegated legislation) dari dua Qanun Aceh sebelumnya, yaitu: Pertama, Pasal 23 ayat (5), Pasal 36 ayat (4), Pasal 50 ayat (4), Pasal 74 ayat (2), Pasal 87 ayat (4), Pasal 100, Pasal 249 ayat (6), Pasal 250 ayat (4), dan Pasal 284 ayat (2) Qanun Aceh Nomor 7 Tahun 2013 tentang Hukum Acara Jinayat. Kedua, Pasal 4 ayat (7), Pasal 67 ayat (2), dan Pasal 68 ayat (4) Qanun Aceh Nomor 6 Tahun 2014 tentang Hukum Jinayat.

Mengacu pada Pasal 262 Qanun Aceh Nomor 7 Tahun 2013 tentang Hukum Acara Jinayat menjelaskan bahwa pada ayat (1) Uqubat cambuk dilaksanakan di suatu tempat terbuka dan dapat dilihat oleh orang yang hadir. Ayat (2) Pelaksanaan Uqubat cambuk dimaksud pada ayat (1) tidak boleh dihadiri oleh anak-anak dibawah umur 18 tahun. Ayat (3) Pelaksanaan Uqubat cambuk dilaksanakan di atas alas (bidang) berukuran minimal 3 × 3 meter. Ayat (4) Jarak antara tempat berdiri terhukum dengan masyarakat penyaksi paling dekat 12 meter. Ayat (5) Jaksa, hakim pengawas, dokter yang ditunjuk dan petugas pencambuk berdiri di atas atau di sekitar alas sebagaimana dimaksud pada ayat (3) selama pencambukan berlangsung.

Sementara, berdasarkan Pasal 30 Peraturan Gubernur Aceh Nomor 5 Tahun 2018 Tentang Pelaksanaan Hukum Acara Jinayat, diatur secara jelas pada ayat (1) tentang pelaksanan Uqubat cambuk dilaksanakan disuatu tempat terbuka dan dapat dilihat oleh orang yang hadir, serta pada ayat (2) Pelaksanaan Uqubat cambuk sebagaimana dimaksud pada ayat (1) tidak boleh dihadiri oleh anak-anak di bawah usia 18 tahun, kemudian pada ayat (3) dijelaskan bahwa tempat terbuka sebagaimana dimaksud pada ayat (1) bertempat di Lembaga Permasyarakatan atau Rumah Tahanan atau Cabang Rumah Tahanan, dan pada ayat (4) Pelaksanaan Uqubat cambuk bertempat di Lembaga Permasyarakatan atau Rumah Tahanan atau Cabang Rumah Tahanan yang dilaksanakan setelah adanya naskah kerjasama antara Pemerintah Aceh dengan Kantor Wilayah Kementerian Hukum dan Hak Azasi Manusia Republik Indonesia. ${ }^{4}$

Berdasarkan hal tersebut, kemudian Pemerintah Aceh Irwandi Yusuf pada saat itu telah melakukan penandatanganan Perjanjian Kerjasama antar Pemerintah Aceh dengan Kantor Kementerian Hukum dan Hak Azasi Manusia Aceh tentang Pelaksanaan Peraturan Gubernur Aceh Nomor 5 tahun 2018 tentang pelaksanaan Hukum Acara Jinayat Nomor : 07/Pks/2018 dan Nomor : W1.107-Pk.01.06 tahun 2018, yang selanjutnya Kementerian Hukum dan Hak Azasi Manusia Aceh bersedia memberikan tempat untuk pelaksanaan uqubat cambuk dilaksanakan dalam Lembaga Permasyarakatan. ${ }^{5}$

Padahal, jika dilihat dari bahasa dalam konteks pelaksanaan cambuk di Lembaga Permasyarakatan atau Rumah Tahanan atau Cabang Rumah Tahanan adalah merupakan kondisi atau tempat yang tidak semua orang umum

${ }^{4}$ Pasal 30 Peraturan Gubernur Aceh No. 5 Tahun 2018 Tentang Pelaksanaan Hukum Acara Jinayat.

${ }^{5}$ Modus Aceh https://modusaceh.co/news/ini-poin-perjanjian-pemerintah-aceh-dankemenkumham-aceh/index.html diunduh 16 November 2019.

Suloh: Jurnal Fakultas Hukum Universitas Malikussaleh, Vol. 9, No. 1, April 2021, pp. 28 - 28 
mengetahuinya atau masyarakat secara luas tidak mengetahui dan bahkan mediapun tidak dapat memantaunya, dimana jika mengacu pada Hukum Acara Jinayat pada hakikat awal pelaksanaan cambuk adalah di muka umum yang orang lain atau masyarakat mudah untuk melihatnya atau mengetahuinya secara langsung. ${ }^{6}$

Namun, pada kenyatannya bahwa kebijakan atau peraturan yang telah ditetapkan oleh Pemerintah Aceh melalui Gubernur Aceh Irwandi Yusuf tersebut menimbulkan permasalahan dan kesulitan bagi para penegak hukum diantaranya Kejaksaan Negeri Aceh Timur khusunya dalam upaya melaksanakan eksekusi cambuk bagi pelaku Jarimah yang berada di Lembaga Permasyarakatan atau Cabang Rutan Langsa di Idi yang berada di wilayah Kabupaten Aceh Timur, dimana berdasarkan keterangan yang diberikan oleh Kepala Lembaga Permasyarakatan Cabang Langsa di Idi Bpk. Effendi dalam dialognya mengatakan bahwa keadaan Lembaga Permasyarakatan Cabang Rutan Langsa di Idi tidak memenuhi standar untuk melaksakan eksekusi cambuk didalamnya, lebih lanjut Bpk. Effendi mengatakan bahwa dalam pelaksanaannya tidak ada sarana dan prasarana serta tidak memenuhi syarat pelaksanaan cambuk, ${ }^{7}$ sehingga dalam pelaksaannnya untuk Uqubat cambuk dilaksanakan di muka umum yang berlokasi di halaman Masjid Agung Idi.

Pelaksanaan Uqubat cambuk di muka umum terhadap pelaku Jarimah itu sendiri sebenarnya sudah pernah berlaku di Provinsi Aceh yaitu sejak tanggal 10 Juni 2005, kemudian tentang petunjuk teknis pelaksanaan Uqubat diperuntukan bagi mereka yang melanggar syariat Islam awalnya ditetapkan dalam Peraturan Gubernur Aceh Nomor 10 Tahun 2005 Tentang Petunjuk Teknis Pelaksanan Hukuman Cambuk dengan diberlakukannya peraturan tentang hukuman cambuk tersebut merupakan keseriusan Pemerintah Daerah Aceh dan masyarakat Aceh untuk melaksanakan Syariat Islam secara utuh, namun dalam pelaksanaannya tidak sesuai harapan sehingga harus dilakukan pengkajian secara mendalam.

Sebagaimana berdasarkan Qanun Aceh Nomor 7 tahun 2013 tentang Hukum Acara Jinayat bahwa Uqubat cambuk adalah sejenis hukuman badan yang dikenakan terhadap terpidana atau pelaku Jarimah yang dilaksanakan dengan cara mencambuk di bagian badan pelaku dengan menggunakan sebuah rotan yang dilakukan oleh algojo (orang yang memukul pelaku jarimah) yang berada di muka umum, dan pelaksanan putusan Mahkamah Syariyah Idi terhadap uqubat cambuk tersebut di wilayah Kabupaten Aceh Timur merupakan kewenangan dan tanggungjawab Jaksa selaku Penuntut Umum pada Kejaksaan Negeri Aceh Timur sesuai pasal 247 ayat 1 Qanun Aceh Nomor 7 tahun 2013.

Pelaksanan uqubat cambuk seharusnya dilaksanakan segera setelah adanya putusan hakim Majelis Mahkamah Syariyah Idi dan salinan kutipan putusan diterima oleh Jaksa Penuntut Umum, namun dalam pelaksanaannya terbentur dengan tidak adanya anggaran, padahal berdasarkan Pasal 284 Qanun Aceh Nomor 7 Tahun 2013 tentang Hukum Acara Jinayat menyebutkan bahwa Pemerintahan Kabupaten/kota berdasarkan Pasal 127 ayat (3) UU RI Nomor 11

\footnotetext{
${ }^{6}$ Pasal 262 ayat 1 Qanun Aceh Nomor 7 Tahun 2013 Tentang Hukum Acara Jinayat.

7 Dialog dengan kepala Lapas Cabang Langsa di Idi Bpk. Effendi di Cabang Lapas Langsa di Idi, tanggal 5 Desember 2018.
}

Suloh: Jurnal Fakultas Hukum Universitas Malikussaleh, Vol. 9, No. 1, April 2021, pp. 29 - 28 
Tahun 2006 tentang Pemerintahan Aceh mengalokasikan dana dan sumber daya lainnya untuk pelaksanaan Hukum Acara Jinayat, namun terkadang pelaksanaan cambuk tidak dapat dilaksanakan hingga tersedianya anggaran dari Pemerintah Daerah di Kabupaten Aceh Timur.

Dengan tidak adanya anggaran untuk pelaksanaan Uqubat cambuk di Kabupaten Aceh Timur terkadang Jaksa Penuntut Umum pada Kejaksaan Negeri Aceh Timur dalam menjalankan tugas dan wewenangnya ketika persidangan dalam Surat Tuntutannya terhadap pelaku Jarimah (perbuatan yang dilarang dan/atau tidak melaksanakan perbuatan yang diperintahkan oleh syariat Islam dalam Qanun Jinayat) menuntut pelaku Jarimah tidak dengan Uqubat cambuk, namun dengan Uqubat penjara yaitu berada di Rutan Cabang Langsa di Idi.

Kajian yang terdahulu seperti Dede Hendra Mr, dalam tesisnya Eksistensi Penerapan Pidana Cambuk Terhadap Pelanggar Qanun Syariat Islam di Provinsi Aceh, dengan hasil penelitian yaitu Petunjuk teknis dari pelaksanaan pidana cambuk di Propinsi Aceh berdasarkan atas Peraturan Gubernur Aceh Nomor 10 Tahun 2005 tentang petunjuk teknis pelaksanaan hukuman cambuk, dan DPRA sedang melakukan pembahasan Hukum Acara Jinayah serta melakukan revisi ketentuan-ketentuan qanun yang memuat materi hukuman cambuk. ${ }^{8}$

Berkaitan dengan penelitian yang penulis tulis terdapat persamaan yaitu terletak pada pelaksanaan pidana cambuk, sedangkan perbedaannya adalah penulis sebelumnya meneliti tentang pelaksanaan pidana cambuk di Propinsi Aceh berdasarkan atas Peraturan Gubernur Aceh Nomor 10 Tahun 2005 tentang petunjuk teknis pelaksanaan hukuman cambuk, sedangkan penulis lebih khusus meneliti terhadap Pelaksanaan Hukum Acara Jinayat menurut Peraturan Gubernur Aceh Nomor 5 Tahun 2018 Tentang Pelaksanan Hukum Acara Jinayat di Kabupaten Aceh Timur.

Delfi Suganda, dalam tesisnya Pancasila dan Syari'at Islam sebagai AsasAsas Pembentukan Qanun di Nanggroe Aceh Darussalam (Studi Kasus Peraturan Daerah Nomor 5 Tahun 2000 Tentang Pelaksanaan Syariat Islam, dengan hasil penelitian yaitu Pancasila merupakan segala sumber hukum di Indonesia, yang menjadi landasan dasar dalam penerapan dan pembentukan hukum nasional dan peraturan daerah. Kehadiran Pancasila menjadikan bentuk penghargaan terhadap produk lokal di Aceh yang bersifat istimewa. Pancasila juga sebagai harmonisasi antara hukum nasional yang berlaku di Aceh dan hukum lokal yang merupakan keinginan masyarakat Aceh sendiri. ${ }^{9}$

Berkaitan dengan penelitian yang penulis tulis terdapat persamaan yaitu terletak pada Peraturan Daerah, sedangkan perbedaannya adalah penulis sebelumnya meneliti mengenai Pancasila dan Syari'at Islam sebagai Asas-Asas Pembentukan Qanun di Nanggroe Aceh Darussalam (Studi Kasus Peraturan Daerah Nomor 5 Tahun 2000 Tentang Pelaksanaan Syariat Islam, sedangkan

${ }^{8}$ Dede Hendra Mr, Eksistensi Penerapan Pidana Cambuk Terhadap Pelanggar Qanun Syariat Islam di Provinsi Aceh, Tesis Program Pascasarjana Universitas Indonesia, Jakarta, 2012.

${ }^{9}$ Delfi Suganda, Pancasila dan Syari'at Islam sebagai Asas-Asas Pembentukan Qanun di Nanggroe Aceh Darussalam (Studi Kasus Peraturan Daerah No. 5 Tahun 2000 Tentang Pelaksanaan Syariat Islam), Tesis Program Pascasarjana Universitas Gajah Mada, Yogjakarta, 2012.

Suloh: Jurnal Fakultas Hukum Universitas Malikussaleh, Vol. 9, No. 1, April 2021, pp. 30 - 28 
penulis meneliti lebih khusus tentang Pelaksanaan Hukum Acara Jinayat menurut Pergub Nomor 5 Tahun 2018 di Kabupaten Aceh Timur.

Khairil Akbar, dalam tesisnya Relevansi Prinsip Pemidanaan Islam Terhadap Sila Ketuhanan Yang Maha Esa (Studi Terhadap Qanun Aceh Nomor 6 Tahun 2014 Tentang Hukum Jinayat), dengan hasil penelitian yaitu bahwa Qanun Jinayah Aceh menganut prinsip keislaman, legalitas, keadilan dan keseimbangan, kemaslahatan, perlindungan HAM, dan prinsip pembelajaran kepada masyarakat. Prinsip-prinsip itu saling berkaitan dan melahirkan prinsip-prinsip baru lainnya, seperti personalitas keislaman, pola sanksi, dan penundukan diri. ${ }^{10}$

Berkaitan dengan penelitian yang penulis tulis terdapat persamaan yaitu sama-sama meneliti relevansi prinsip pemidanaan Islam, sedangkan perbedaannya adalah peneliti sebelumnya mengenai relevansi prinsip pemidanaan Islam terhadap sila Ketuhanan Yang Maha Esa (Studi Terhadap Qanun Aceh Nomor 6 Tahun 2014 Tentang Hukum Jinayat), sedangkan penulis lebih khusus meneliti tentang Pelaksanaan Hukum Acara Jinayat menurut Pergub Aceh Nomor 5 Tahun 2018 di Kabupaten Aceh Timur.

Berdasarkan dari latar belakang tersebut, penulis tertarik karena terdapat permasalah dalam penulisan ini yaitu bagaimana Pelaksanaan Peraturan Gubernur Aceh Nomor 5 Tahun 2018 oleh Jaksa di Kabupaten Aceh Timur, dan mengapa pelaksanaan Peraturan Gubernur Aceh Nomor 5 Tahun 2018 di Kabupaten Aceh Timur masih mengalami hambatan.

\section{B. MetodePenelitian}

Metode penelitian yang Penulis gunakan dalam penulisan ini yaitu menggunakan metode penelitian sebagai berikut :

\section{Pendekatan Penelitian}

Penulis menggunakan pendekatan yuridis empiris yaitu penelitian yang pada kenyataannya dibuat dan diterapkan oleh manusia yang hidup pada masyarakat guna memahami kondisi atau situasi sosial kemasyarakatan dimana hukum tersebut diterapkan, ${ }^{11}$ pendekatan yuridis empiris tersebut meneliti dengan menggunakan data sekunder terlebih dahulu dan dilanjutkan dengan menggunakan data primer di lapangan sebagai bahannya. ${ }^{12}$

Penelitian ini menggunakan jenis penelitian kualitatif (qualitative approach) yaitu suatu cara analisis hasil penelitian yang menghasilkan data deskritif analisis, yaitu data yang dinyatakan oleh responden secara tertulis yang diteliti dan dipelajari sebagai suatu yang utuh. ${ }^{13}$ Guna mengetahui Pelaksanaan

${ }^{10}$ Khairil Akbar, Relevansi Prinsip Pemidanaan Islam Terhadap Sila Ketuhanan Yang Maha Esa (Studi Terhadap Qanun Aceh Nomor 6 Tahun 2014 Tentang Hukum Jinayat), Tesis Program Pascasarjana Universitas Islam Indonesia, Yogjakarta, 2017.

${ }^{11}$ Mukti Fajar dan Yulianto Achmad, Dualisme Penelitian Hukum Normatif dan Empiris, Yogyakarta: Pustaka Pelajar, 2010, hlm.44.

${ }^{12}$ Muhammad Hilmi Akhsin, Anis Mashdurohatun, Akibat Hukum Jaminan Fidusia Yang Tidak Didaftarkan Menurut UU No. 42 Tahun 1999, Jurnal Akta, Vol.4 No. 3, 2017.

${ }^{13}$ Ibid, hlm. 192.

Suloh: Jurnal Fakultas Hukum Universitas Malikussaleh, Vol. 9, No. 1, April 2021, pp. 31 - 28 
Peraturan Gubernur Aceh Nomor 5 Tahun 2018 oleh Jaksa Penuntut Umum pada Kejaksaan Negeri Aceh Timur.

\section{Bahan Hukum}

Bahan hukum yang Penulis gunakan untuk yaitu :

a. Bahan Hukum Primer

Penulis mengambil bahan hukum yang mempunyai otoritas (autoritatis), terdiri atas peraturan perundang-undangan, catatan resmi atau risalah dalam pembuatan suatu perundang-undangan, dan putusan hakim ${ }^{14}$ dan dokumen resmi negara. ${ }^{15}$

Dalam penelitian hukum sosiologis dibangun dari fakta-fakta sosial terkait dengan bekerjanya hukum secara nyata yang dihadapi oleh penulis, serta pengamatan secara langsung melalui observasi, kuesioner, atau wawancara terhadap Ketua Mahkamah Syar'iyah Idi, Kepala Kejaksan Negeri Aceh Timur, Kepala Rutan Idi, Kepala Satuan Polisi Pomong Praja dan Wilayatul Hisbah Kabupaten Aceh Timur, Kepala Dinas Syariat Islam. ${ }^{16}$

b. Bahan Hukum Sekunder

Penulis mengambil publikasi tentang hukum yang merupakan dokumentasi tidak resmi, baik dari buku-buku teks yang membicarakan suaru permasalahan hukum, skripsi, tesis, disertasi hukum, kamus-kamus hukum, jurnal-jurnal hukum, komentar-komentar atas putusan hakim, ${ }^{17}$ kamus hukum, ensiklopedia hukum, atau wawancara dengan narasumber seorang ahli hukum untuk memberikan pendapat hukum tentang suatu fenomena. ${ }^{18}$

\section{Metode Pengumpulan Data}

Metode pengumpulan data yang penulis gunakan yaitu:

a. Metode pengumpulan data kepustakaan yang penulis peroleh melalui penelitian kepustakaan yang bersumber dari peraturan perundang-undangan, buku-buku, dokumen resmi, publikasi, dan hasil penelitian;

b. Wawancara yang dilakukan melalui wawancara berencana ${ }^{19}$ yang disertai dengan suatu daftar pertanyan yang telah disusun sebelumnya, dengan narasumber yaitu Kepala Kejaksaan Negri Aceh Timur, Kepala Lapas Kelas II B Idi, Hakim Mahkamah Syariyah Idi, Kepala Dinas Syariat Islam Kab. Aceh Timur dan Kepala Satuan Polisi Pamong Praja dan Wilayatul Hisbah Kab. Aceh Timur;

c. Observasi dengan melakukan pengamatan di dalam Lapas Kelas II B Idi untuk mengetahui secara langsung situasi dan kondisi yang sebenarnya.

${ }^{14}$ Zainuddin Ali, Metode Penelitian Hukum, Jakarta : Sinar Grafika, Cet. ke-8, 2016,hlm. 47.

${ }^{15}$ Mukti Fajar dan Yulianto Achmad, hlm.42.

${ }^{16}$ Mukti Fajar dan Yulianto Achmad, hlm.59.

${ }^{17}$ Zainuddin Ali, hlm. 54.

${ }^{18}$ Mukti Fajar dan Yulianto Achmad, hlm.43.

${ }^{19}$ Amiruddin, Zainal Asikin, Pengantar Metode Penelitian Hukum, Jakarta: PT. Raja Grafindo Persada, Cet-I, 2004, hlm. 84.

Suloh: Jurnal Fakultas Hukum Universitas Malikussaleh, Vol. 9, No. 1, April 2021, pp. 32 - 28 


\section{Analisis Data}

Setelah semua data yang penulis butuhkan telah terkumpul, kemudian dilakukan pemeriksaan terhadap data tersebut baik melalui wawancara dan inventarisasi data tulis, yang kemudian diolah dan disusun secara sistematis.

Analisis data yang penulis gunakan dalam penulisan tesis ini dianalisis menggunakan sifat analisis deskriptif, maksudnya dalam menganalisis penulis memberikan gambaran atau pemaparan atas subjek dan objek penelitian sebagaimana penelitian yang dilakukan, serta bersifat evaluatif yaitu memberikan penilaian atas hasil penelitian atau justifikasi, apakah hipotesis dari teori hukum yang diajukan diterima atau ditolak, dan bersifat preskriptif untuk memberikan argumentasi atas hasil penelitian yang telah dilakukan, guna memberikan penilaian mengenai benar atau salah atau apa yang seyogianya menurut hukum terhadap fakta dan peristiwa hukum dari hasil penelitian.

Analisis data dalam penelitian ini berupa kajian atau telaah terhadap hasil pengolahan data dibantu dengan teori-teori yang telah didapatkan sebelumnya, sehingga sebagai bahan telaah yang dapat berarti menentang, mengkritik, mendukung, menambah, atau memberikan komentar serta membuat kesimpulan terhadap hasil penelitian dengan pikiran sendiri dan bantuan teori yang dikuasai. ${ }^{20}$

\section{Hasil Penelitian dan Pembahasan}

\section{Pelaksanaan Peraturan Gubernur Aceh Nomor 5 Tahun 2018 oleh Jaksa di Kabupaten Aceh Timur}

Istilah Jaksa Penuntut Umum sebenarnya terdapat perbedaan makna antara Jaksa dengan Penuntut Umum. Kedua istilah tersebut dapat kita temukan dalam Pasal 1 angka 6 UU RI Nomor 8 Tahun 1981 tentang Hukum Acara Pidana (KUHAP) yang berbunyi Jaksa adalah pejabat yang diberi wewenang oleh undang-undang ini untuk bertindak sebagai penuntut umum serta melaksanakan putusan pengadilan yang telah memperoleh kekuatan hukum tetap, sedangkan Penuntut umum adalah Jaksa yang diberi wewenang oleh undang-undang ini untuk melakukan penuntutan dan melaksanakan penetapan hakim, sehingga terciptanya penegakan hukum dimasyarakat.

Penegakan hukum yang biasa didengar dengan istilah law enforcement tidak akan bermanfaat jika penegakan yang dilakukan oleh aparat penegak hukum tidak sesuai dengan kaidah-kaidah penegakan hukum yang benar. Hukum yang benar adalah hukum yang diangkat dari norma hidup masyarakat yang sesuai dengan rasa keadilan di masyarakat, maka dengan demikian tujuan hukum akan tercapai. ${ }^{21}$

Dalam suatu riwayat, Rasulullah salalahu a'laihi wasallam pernah bersabda yang maksudnya yaitu "Tuhan tidak akan menerima iman seseorang kalau tidak diwujudkan dalam amal perbuatan, dan Tuhan tidak akan menerima amal perbuatan yang tidak terpancar dari keimanan." Dengan demikian penegakan

${ }^{20}$ Mukti Fajar dan Yulianto Achmad, hlm. 183.

${ }^{21}$ Busthanul Arifin, Pelembagaan Hukum Islam di Indonesia Akar Sejarah, Hambatan, dan Prospeknya, Jakarta; Gema Insani Press, Cet ke-I, 1996, hlm. 26.

Suloh: Jurnal Fakultas Hukum Universitas Malikussaleh, Vol. 9, No. 1, April 2021, pp. 33 - 28 
hukum tidak mengenal kompromi, dan penegakan hukum didasarkan kepada kesaman kedudukan manusia, bukan status sosial masyarakat. ${ }^{22}$

Makna integrated criminal justice system menurut Muladi adalah sinkronisasi atau keserampakan dan keselarasan, yang dibedakan menjadi sinkronisasi struktural (structural sincronization) yaitu keselarasan dalam rangka hubungan antar lembaga penegak hukum, kedua, sinkronisasi substansial (substansial sincronization) yaitu keselarasan yang bersifat vertikal dan horizontal kaitannya dengan hukum positif, ketiga sinkronisasi kultural (cultural sincronization) yaitu keselarasan dalam menghayati pandangan, sikap-sikap, dan falsafah yang mendasari jalannya sistem peradilan pidana, yang ketiganya harus terealisasikan dalam pelaksanan Pergub tersebut. ${ }^{23}$

Seharusnya dengan adanya Peraturan Gubernur Aceh Nomor 5 tahun 2018 tersebut dapat terjadi efektivitas hukum dalam penerapannya sehingga masyarakat menyadari dan tidak melakukan perbuatan yang dilarang. Efektivitas hukum menurut Anthony Allot bahwa hukum akan menjadi efektif apabila tujuan keberadaan dan penerapannya dapat mencegah perbuatan-perbuatan yang tidak diinginkan dapat menghilangkan kekacauan. ${ }^{24}$

Pelaksanaan Hukum Acara Jinayat berupa hukuman cambuk, diadopsi dari hukum Islam atau jinayat yang hanya ada dan berlaku di Provinsi Aceh yang mendapat kewenangan secara legalitas untuk menerapkan syariat Islam yang secara jelas termuat dalam Undang-undang Pemerintah Aceh (UUPA) Nomor 11 tahun 2006, dimana dalam pelaksanannya dituangkan melalui Qanun Aceh Nomor 7 tahun 2013 tentang Hukum Acara Jinayat dan diperjelas mengenai pelaksanaanya melalui Peraturan Gubernur Aceh Nomor 5 tahun 2018 tentang Pelaksanan Hukum Acara Jinayat, yang memperjelas pelaksanaan Uqubat cambuk di dalam Lembaga Permasyarakat dalam hal ini di Lapas Kelas II B Idi yang kini menjadi kendala.

Di Aceh sendiri sebelum Qanun Aceh Nomor 7 tahun 2013 tentang Hukum Acara Jinayat dan Peraturan Gubernur Nomor 5 tahun 2018 tentang Pelaksanan Hukum Acara Jinayat, penerapan hukuman cambuk sudah pernah dibentuk dan diberlakukan sebelumnya melalui Peraturan Gubernur Aceh Nomor 10 tahun 2005 Tentang Petunjuk Teknis Pelaksanaan Uqubat Cambuk Gubernur Provinsi Nanggroe Aceh Darusallam, yang menghukum terhadap tiga kasus pelanggaran syariat Islam dengan cambuk yaitu khamar (minuman berakohol), maisir (perjudian), dan khalwat (perbuatan berlainan jenis di tempat tertutup). ${ }^{25}$

Namun, dalam perkembangannya telah diperluas di dalam Qanun Aceh Nomor 6 tahun 2014 Pasal 3 Ayat 2 tentang perbuatan jarimah berupa khamar, maisir, khalwat, ihktilat, zina, pelecehan seksual, pemerkosaan, qadzaf, liwath, dan musahaqah, yang keseluruhan jarimah tersebut Jaksa Penuntut Umum berwenang mengajukan perkara atau menyidangkan ke Mahkamah Syar'iyah Idi

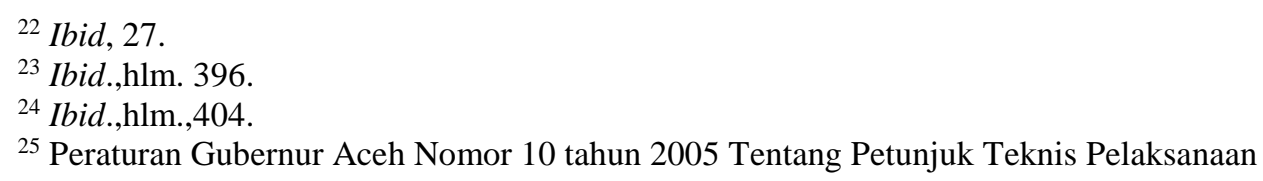

Suloh: Jurnal Fakultas Hukum Universitas Malikussaleh, Vol. 9, No. 1, April 2021, pp. 34 - 28 
hingga melaksanakan putusan pengadilan sebagaimana diatur dalam Pasal 15 dan Pasal 16 Qanun Aceh Nomor 7 tahun 2013 tentang Hukum Acara Jinayat.

Uqubat cambuk yang diterapkan dalam qanun maupun Peraturan Gubernur tersebut merupakan salah satu bentuk hukuman had atau jenis kejahatan yang telah ditetapkan oleh syara seperti zina, qazaf, dan khamar, hukuman cambuk tersebut merupakan salah satu pilihan utama dalam penetapan sanksi terhadap jarimah $t a$ 'zir, hal ini disebabkan karena hukuman cambuk dianggap memberikan efek yang lebih baik dari beberapa sanksi ta'zir lainnya seperti penjara, pengasingan dan denda. ${ }^{26}$

Hukuman cambuk sendiri berasal dari bahasa Arab dari akar kata jald. Kata jald berasal dari kata jalada, yajlidu, jaldan yang berarti memukul di kulit atau memukul dengan cambuk yang terbuat dari kulit, namun dalam prakteknya dan berdasarkan aturan dalam Qanun Acara Jinayat, alat yang digunakan dalam cambuk tersebut terbuat dari bahan rotan. Hukuman cambuk menurut Ali Sodiqin yang diberikan tersebut harus menyebabkan rasa sakit, diberlakukan kepada pelanggar hukum dalam bentuk nyata, dilaksanakan dengan sengaja oleh pelaku, dan ditegakan oleh otoritas yang ditunjuk dalam hal ini oleh Jaksa sebagai eksekutor pelaksaan Uqubat cambuk. ${ }^{27}$

Pelaksanaan hukuman cambuk berdasarkan Peraturan Gubernur Nomor 5 tahun 2018 tentang Pelaksanan Hukum Acara Jinayat yang dilakukan oleh Jaksa Penuntut Umum hinga kini belum dapat dilaksanakan di Lembaga Permasyarakatan atau di Lapas Kelas II B Idi sebagaimana amanat Pasal 30 ayat (3) Peraturan Gubernur Aceh Nomor 5 Tahun 2018 tersebut.

Beberapa faktor dilapangan menjadi penyebab tidak terlaksananya eksekusi cambuk di dalam Lembaga Permasyarakatan (Lapas) Kelas II B Idi, hal ini dikarenakan tidak tersedianya sarana dan prasarana, keterbatas tempat dikarenakan pelaksanaan cambuk terdapat ketentuan mengenai jarak dan ukuran panggung eksekusinya, serta dikhawatirkan apabila dilaksanakan di dalam lapas timbul keributan dari para warga binaan (narapidana), dan apabila eksekusi cambuk dilaksanakan di dalam Lapas, maka masyarakat pada umumnya tidak mengetahuinya atau tidak dapat melihat langsung, mengingat terdapat warga binaan di dalam Lapas, padahal tujuan utama dari eksekusi cambuk di muka umum adalah untuk memberikan efek jera dan efek malu bagi pelaku. ${ }^{28}$

Senada disampaikan oleh Kepala Satuan Polisi Pamong Praja dan Wilayatul Hisbah Kab. Aceh Timur bahwa pelaksanan Uqubat cambuk di dalam Lembaga Permasyarakatan tidak memenuhi standar sesuai yang di jelaskan dalam Qanun Acara Jinayat untuk melaksanakan uqubat cambuk di Lapas, dan juga efek yang muncul jika dilaksanakan di dalam Lembaga Permasyarakatan tidak adanya rasa

${ }^{26}$ Muslim Zainuddin, Problematika hukuman cambuk di Aceh, Aceh: Dinas Syariat Islam Aceh, Edisi Pertama, 2011, hlm.1.

${ }^{27}$ Ibid, hlm 9.

${ }^{28}$ Wawancara Eka Priyatna, Kepala lapas Kelas II B Idi, Selasa, 25 Februari 2020, 10.3011.30 Wib, Ruang Kalapas Kelas II B Idi.

Suloh: Jurnal Fakultas Hukum Universitas Malikussaleh, Vol. 9, No. 1, April 2021, pp. 35 - 28 
malu dari pelaku jarimah dikarenakan masyarakat luas tidak mengetahuinya, dan dikhawatirkan terjadi keributan di dalam lapas. ${ }^{29}$

Pelaksanaan uqubat cambuk di Lapas dapat dilaksanakan setelah adanya perjanjian naskah kerjasama antara Pemerintah Aceh dengan Kantor Wilayah Kementerian Hukum dan Hak Azasi Manusia Republik Indonesia dalam pelaksanaan Uqubat cambuk bertempat di Lembaga Permasyarakatan atau Rumah Tahanan atau Cabang Rumah Tahanan, namun kenyataannya hingga saat ini di Lapas Kelas II B Idi belum ada petunjuk teknis atau petunjuk pelaksana dari naskah kerjasama tersebut, sehingga pelaksanaan cambuk di Lapas belum dapat dilaksanakan. ${ }^{30}$

Pelaksanan cambuk tersebut selama ini dilaksanakan oleh Jaksa sebagai eksekutor dalam melaksanakan tugas dan wewenangnya dalam penyelesaian perkara Jinayat di Kabupaten Aceh Timur. Perkara jinayat yang telah diajukan ke persidangan di Mahkamah Syariyah Idi dengan rincian perkara yaitu pada tahun 2018 sebanyak 17 perkara, tahun 2019 sebanyak 9 perkara, dan pada tahun 2020 sebanyak 2 perkara, dengan rincian sebagai berikut $:{ }^{31}$

Tabel 1.

Perkara yang telah disidangkan oleh Jaksa Pada Kejaksaan Negeri Aceh

Timur pada tahun 2018 di Mahkamah Syar'iyah Idi.

\begin{tabular}{|c|l|c|c|c|}
\hline No & \multicolumn{1}{|c|}{ Nama Pelaku Jarimah } & Jenis Jarimah & Hukuman & Tahun \\
\hline 1 & Ishak Bin Abdurahman & Maisir (Judi) & Penjara & 2018 \\
\hline 2 & Sunardi Bin Samaun & Maisir (Judi) & Penjara & 2018 \\
\hline 3 & Mawardi Bin Abidin & Maisir (Judi) & Penjara & 2018 \\
\hline 4 & Serik Anggrini Sari Binti Paidi & Maisir (Judi) & Cambuk & 2018 \\
\hline 5 & $\begin{array}{l}\text { Ivan Irfandi Alias Pen Bin } \\
\text { Kamaruddin }\end{array}$ & Maisir (Judi) & Cambuk & 2018 \\
\hline 6 & $\begin{array}{l}\text { Abdullah Bin Abdurrahman } \\
\text { Abu Bakar Bin Mahmuddin }\end{array}$ & Maisir (Judi) & Penjara & 2018 \\
\hline 7 & $\begin{array}{l}\text { Husaini Bin A. Rahman } \\
\text { Kusno Bin Junet } \\
\text { Rizal Bin Baringat Kanaramadhani Bin } \\
\text { Revi } \\
\text { Jamadoni }\end{array}$ & Maisir (Judi) & & \\
\hline 8 & M. Waled Bin Saifuddin Alias Reza Bin & Maisir (Judi) & Penjara & 2018 \\
\hline 9 & $\begin{array}{l}\text { Fahmirzal Alias Nadar Bin } \\
\text { Ramlani }\end{array}$ & Maisir (Judi) & Penjara & 2018 \\
\hline 10 & $\begin{array}{l}\text { Nazaruddin Alias } \\
\text { Arifin }\end{array}$ & $\begin{array}{l}\text { Maisir (Judi) } \\
\text { T. Arif Fadilah Bin T. M. Nur Azhari Alias Heri Alias } \\
\text { Wak Genk Bin Rusli }\end{array}$ & Penjara & 2018 \\
\hline 12 & Sayuti Nur Bin M.Diah & Maisir (Judi) & Penjara & 2018 \\
\hline 13 & Wendi Syahputra Bin Ilyas Abu & Maisir (Judi) & Penjara & 2018 \\
\hline
\end{tabular}

${ }^{29}$ Wawancara Teuku. Amran, Kasat Pol PP dan WH Kab. Aceh Timur, Rabu, 26 Februari 2020, 14.30-15.30 wib, Ruang Kasat Pol PP dan WH Kab. Aceh Timur.

${ }^{30}$ wawancara Eka Priyatna., Loc.Cit.

${ }^{31}$ wawancara Bpk T. Swandi, Bpk. Abun Hasbulloh Syambas, dan Bpk. Eka Priyatna. 


\begin{tabular}{|c|l|c|c|c|}
\hline & Bakar & & & \\
\hline 14 & $\begin{array}{l}\text { Haris Ismu Nanda Alias Laneng } \\
\text { Bin M. Yusuf }\end{array}$ & Maisir (Judi) & Penjara & 2018 \\
\hline 15 & Agus Slim Bin Nurdin & Maisir (Judi) & Penjara & 2018 \\
\hline 16 & $\begin{array}{l}\text { Salahuddin Alias Dek Gam Bin } \\
\text { Zakaria }\end{array}$ & Maisir (Judi) & Penjara & 2018 \\
\hline 17 & $\begin{array}{l}\text { Fahrurazi Bin Hasan } \\
\text { Hamdani Alias Si Pon Bin } \\
\text { Usman } \\
\text { Usman Bin Abdullah Safii } \\
\text { Hamdani Bin Mahdi }\end{array}$ & Penjara & 2018 \\
\hline
\end{tabular}

Tabel tersebut diatas, penulis peroleh dari hasil wawancara yang penulis lakukan pada hari Kamis tanggal 27 Februari 2020 sekira pukul 10.30-11.30 wib di Ruang Hakim Mahkamah Syari'yah Idi kepada narasumber Bpk T. Swandi Hakim Mahkamah Syari'yah Idi dan wawancara kepada Bpk. Abun Hasbulloh Syambas Kepala Kejaksaan Negeri Aceh Timur pada hari Selasa tanggal 03 Maret 2020 sekira Pukul 09.00-10.00 Wib di Ruang Kepala Kajaksaan Negeri Aceh Timur.

Tabel 2.

Perkara yang telah disidangkan oleh Jaksa Pada Kejaksaan Negeri Aceh Timur pada tahun 2019 di Mahkamah Syar'iyah Idi.

\begin{tabular}{|c|l|c|c|c|}
\hline No & Nama Pelaku Jarimah & $\begin{array}{c}\text { Jenis } \\
\text { Jarimah }\end{array}$ & Hukuman & Tahun \\
\hline 1 & $\begin{array}{l}\text { Muhammad Iqbal Alias Si Bal } \\
\text { Bin Sofyan }\end{array}$ & Maisir (Judi) & Penjara & 2019 \\
\hline 2 & $\begin{array}{l}\text { Ziaul Akbar Alias Akbar Bin } \\
\text { Zamhir }\end{array}$ & Maisir (Judi) & Penjara & 2019 \\
\hline 3 & Tarmizi Alias Mahdi Bin Hasyim & Maisir (Judi) & Penjara & 2019 \\
\hline 4 & Ruslan Bin Usman & Maisir (Judi) & Penjara & 2019 \\
\hline 5 & Syahrial Bin Zainuddin & Maisir (Judi) & Penjara & 2019 \\
\hline 6 & Erwinsyah Bin Muhammad Hasan & Maisir (Judi) & Penjara & 2019 \\
\hline 7 & $\begin{array}{l}\text { Sakilawati Binti Mustafa } \\
\text { Iskandar Bin Umar Ibrahim }\end{array}$ & $\begin{array}{c}\text { Ditempatkan } \\
\text { di Dayah di } \\
\text { Madat } \\
\text { Cambuk }\end{array}$ & 2019 \\
\hline 8 & $\begin{array}{l}\text { Khairul Ihsan Bin Iskandar } \\
\text { Hasyim }\end{array}$ & Zina & Cambuk & 2019 \\
\hline 9 & Sakilawati Binti Mustafa & Zina & Cambuk & 2019 \\
\hline
\end{tabular}

Tabel tersebut diatas, penulis peroleh berdasarkan hasil wawancara oleh Bpk T. Swandi Hakim Mahkamah Syari'yah Idi pada hari Kamis tanggal 27 Februari 2020 sekira pukul 10.30-11.30 wib di Ruang Hakim Mahkamah Syari'yah Idi, wawancara Bpk. Abun Hasbulloh Syambas Kepala Kejaksaan Negeri Aceh Timur pada hari Selasa tanggal 03 Maret 2020 sekira Pukul 09.0010.00 Wib di Ruang Kepala Kajaksaan Negeri Aceh Timur, dan Bpk. Eka Priyatna Kepala Lembaga Permasyarakatan Kelas II B Idi pada hari Selasa 
tanggal 25 Februari 2020 sekira pukul 10.30-11.30 Wib di Ruang Kalapas Kelas II B Idi.

Tabel 3.

Perkara yang telah disidangkan oleh Jaksa Pada Kejaksaan Negeri Aceh Timur pada tahun 2019 di Mahkamah Syar'iyah Idi.

\begin{tabular}{|c|l|c|c|c|}
\hline No & Nama Pelaku Jarimah & Jenis Jarimah & Hukuman & Tahun \\
\hline 1 & Sawaludin Bin Abdul Wahab & Maisir (Judi) & Cambuk & 2020 \\
\hline 2 & $\begin{array}{l}\text { Ibrahim Is Alias Apa Him Bin } \\
\text { Ismail. } \\
\text { Tarmizi Alias Bagok Bin } \\
\text { Abdul Hamid. }\end{array}$ & Cambuk & 2020 \\
\end{tabular}

Tabel tersebut diatas, penulis peroleh dari hasil wawancara yang dilakukan penulis dari narasumber Bpk T. Swandi Hakim Mahkamah Syari'yah Idi, Bpk. Abun Hasbulloh Syambas Kepala Kejaksaan Negeri Aceh Timur, dan Bpk. Eka Priyatna Kepala Lembaga Permasyarakatan Kelas II B Idi.

Jaksa dalam melaksanakan sidang perkara Jinayat yang selama ini berdasarkan pada Qanun Jinayat Nomor 7 Tahun 2013 tentang Hukum Acara Jinayat sebagai pelaksanaan hukum acaranya serta pelaksanaan eksekusinya, mengingat bahwa Peraturan Gubernur Aceh Nomor 5 Tahun 2018 secara internal di Kejaksaan Negeri Aceh Timur belum ada aturan pelaksanaannya seperti Petunjuk Teknis atau Petunjuk Pelaksanaan dari pimpinan Kejaksaan Tinggi Aceh mengenai pelaksanaan cambuk di dalam Lembaga Permasyarakatan. ${ }^{32}$

Senada dengan hal tersebut, Hakim Mahkamah Syariyah Idi menyampaikan mengenai penjatuhan putusan terhadap pelaku jarimah mengacu kepada Qanun Jinayat Nomor 7 Tahun 2013 tentang Hukum Acara Jinayat, yang sangat bervariasi terhadap putusan tersebut yaitu ada yang pelaku dipenjara ada juga yang di cambuk, dan untuk pelaksaan cambuk tidak dilaksanakan di dalam Lapas Kelas II B Idi, melainkan dilaksanakan di muka umum yaitu di lingkungan Masjid Agung Darussholihin Kota Idi Rayeuk.

Jaksa dalam melaksanaan uqubat cambuk untuk selama ini tidak mengacu pada Peraturan Gubernur Nomor 5 tahun 2018 yang disebutkan berada di dalam Lembaga Permasyarakatan dalam hal ini Lapas Kelas II B Idi, karena roh dari Qanun Jinayat Nomor 7 Tahun 2013 tentang Hukum Acara Jinayat yaitu menimbulkan efek malu guna mencegah masyarakat yang melihatnya tidak akan melakukan perbuatan jarimah tersebut. ${ }^{33}$

Mengutip pendapat Widodo Ekatjahjana, Aberr Bashier Dababneh dan Eid Ahmad Al Husban sebaiknya agar peraturan gubernur tersebut dapat dilaksanakan dengan baik dalam awal pembentukan Peraturan Gubernur Aceh Nomor 5 tahun 2018 Gubernur Aceh pada saat itu haruslah memenuhi atau memperhatikan asas-

${ }^{32}$ wawancara Abun Hasbulloh Syambas, Loc. Cit.

33 wawancara T. Swandi, Hakim Mahkamah Syari’yah Idi, Kamis, 27 Februari 2020, 10.30-11.30 wib, Ruang Hakim Mahkamah Syari’yah Idi.

Suloh: Jurnal Fakultas Hukum Universitas Malikussaleh, Vol. 9, No. 1, April 2021, pp. 38 - 28 
asas pembentukan peraturan perundang-undangan yang baik, sehingga dapat dilaksanakan diantaranya yaitu memperhatikan politik hukum yang ada, dapat dilakukan pengujian terhadapnya, masuk akal sehingga orang awam atau masyarakat mudah mengetahui dan memahami, sederhana sehingga dapat mencapai tujuan yang ada, dan harus sesuai dengan aturan hukum yang lebih tinggi.

Kebijakan yang dikeluarkan oleh Gubernur Aceh berupa Peraturan Gubernur Nomor 5 tahun 2018 tersebut terkesan tergesa-gesa tidak memperhatikan atau mengkaji kondisi Lembaga Permasyarakat atau Rumah Tahanan yang berada di daerah-daerah Aceh khususnya di Kabupaten Aceh Timur, padahal dalam mengambil kebijakan Gubernur Aceh harus memperhatikan tahapan proses penegakan hukum yaitu: pertama, tahap kebijakan formulatif atau tahap kebijakan legislatif yaitu tahap penyusunan/perumusan hukum, kedua tahap kebijakan yudikatif atau aplikatif yaitu tahap penerapan hukum, ketiga tahap kebijakan eksekutif atau administrasi yaitu tahap pelaksanaan atau eksekusi. ${ }^{34}$

Artinya pada tahap pertama saja kebijakan berupa penerbitan Peraturan Gubernur Aceh Nomor 5 tahun 2018 tersebut tidak terumuskan secara baik sehingga saat ini tidak dapat dilaksanakan, dan pada penerapan hukum pada tahap kedua mengakibatkan tidak dapat berjalan di lapangan, sehingga mengakibatkan pelaksanaannnya tetap dilaksanakan di muka umum, sebagaimana dalam gambar berikut :

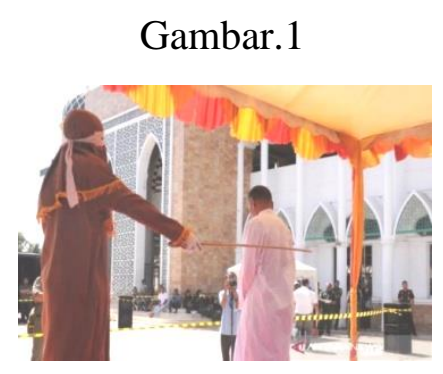

Gambar diatas adalah salah satu dari pelaksanaan cambuk di tempat terbuka bukan di Lapas Kelas II B Idi yang disaksikan oleh Hakim Pengawas, Jaksa, dan Tim Medis serta masyarakat yang dilakukan oleh Jaksa sebagai eksekutor pada Kejaksaan Negeri Aceh Timur terhadap terpidana jarimah maisir jenis batu domino yang dieksekusi cambuk setelah diputus bersalah menurut hukum oleh Mahkamah Syariyah Idi melanggar Pasal 18 Qanun Aceh Nomor 6 Tahun 2014 tentang Hukum jinayat bertempat di halaman Masjid Agung Darussalihin Kota Idi Rayeuk Kabupaten Aceh Timur. ${ }^{35}$

Mengutip pendapat Lawrence M. Friedman bahwa dalam penerapan Peraturan Gubernur Nomor 5 tahun 2018 tersebut terdiri dari tiga komponen, yaitu komponen struktur hukum (legal structure), substansi hukum (legal substance) dan budaya hukum (legal culture), dalam struktur hukum (legal structure) diperlukan suatu sistem yang selaras dalam pelaksanaan cambuk tersebut yaitu dari aparatur penegak hukumnya baik Polisi, Penyidik PPNS dari

${ }^{34}$ Marwan Effendy.,Loc.Cit.,hlm. 227.

35 Antaraaceh, https://aceh.antaranews.com/berita/122966/tiga-terpidana-maisir-dihukumcambuk-di-aceh-timur, diunduh tanggal 30 Mei 2020.

Suloh: Jurnal Fakultas Hukum Universitas Malikussaleh, Vol. 9, No. 1, April 2021, pp. 39 - 28 
Satpol PP dan WH, Kejaksaan, Mahkamah Syariyah, dan Lembaga Permasyarakatan Kelas II B Idi, dalam substansi hukum (legal substance) dimana Peraturan Gubernur Nomor 5 tahun 2018 dibentuk harus dapat dilaksanakan, dan perlu adanya qanun sendiri yang mengatur tugas dan fungsi Kejaksaan di daerah Aceh, sebagaimana telah dibuat sebelumnya Qanun Provinsi Nomor 11 tahun 2004 tentang Fungsional Kepolisian Daerah Nanggroe Aceh Darusalam, adapun kultur atau budaya hukum (legal culture) merupakan sikap dan keyakinan Jaksa dalam menerapkan hukuman terhadap pelaku jarimah. ${ }^{36}$

Penerapan hukuman cambuk bagi pelaku jarimah yang dituntut dan diputus oleh Hakim Mahkamah Syari'yah Idi sudah sesuai dengan hukum modern dilihat dari aspek perkembangan dan pembaruan hukum Islam saat ini yaitu penetapan hukuman cambuk sebagai hukuman alternatif bagi pelanggaran syariat Islam di Aceh, dan hukuman cambuk merupakan ijtihat para fuqaha sesuai amanat UU Nomor 44 Tahun 1999 dan UU Nomor 11 Tahun 2006 dalam merumuskan Qanun syariat Islam di Aceh yang dituangkan dalam bentuk Qanun sebagai hukum positif yang berlaku di Aceh. ${ }^{37}$

Berikut alur proses penegakan hukum yang dilakukan oleh Jaksa Penuntut Umum Pada Kejaksaaan Negeri Aceh Timur terhadap pelaku Jarimah berdasarkan Qanun Aceh No. 7 tahun 2013 Tentang Hukum Acara Jinayat, sebagai berikut :

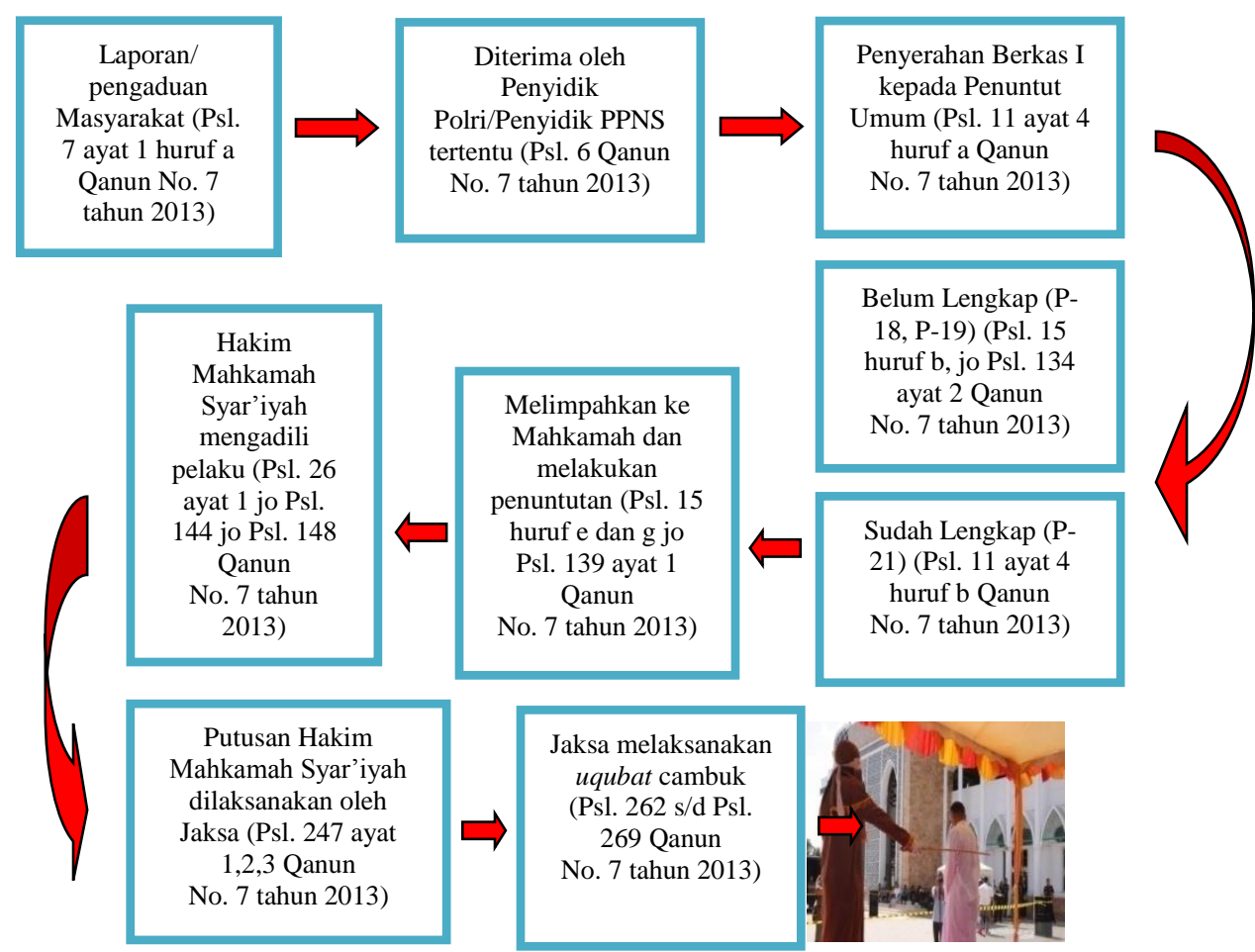

Adapun tujuan hukuman yang diberikan terhadap pelaku dalam syariat Islam dapat dilihat dari dua hal yaitu : pertama, pencegahan (al-rad-u wa al-zajr)

${ }^{36}$ Natangsa Surbakti, Problematika Penegakan Hukum Undang-Undang Penghapusan Kekerasan Dalam Rumah Tangga, Jurnal Ilmu Hukum, Vol. 9, No. 1, Maret 2006, hlm. 101.

${ }^{37}$ Abdul Gani Isa, Formalisasi Syari'at Islam di Aceh (Pendekatan Adat, Budaya, dan Hukum), Aceh: Yayasan Pena Banda Aceh, Cet-I, 2013, hlm. 415.

Suloh: Jurnal Fakultas Hukum Universitas Malikussaleh, Vol. 9, No. 1, April 2021, pp. 40 - 28 
yaitu menahan orang berbuat jarimah agar tidak mengulangi perbuatan jarimah, atau agar tidak terus-menerus melakukan jarimah, berat ringan hukuman ta'zir yang ditentukan atau dituntut oleh Jaksa Penuntut Umum tergantung dari pelanggaran yang dilakukan oleh pelaku jarimah, sebab ada yang diberi peringatan atau nasihat saja, ada berupa cambuk, berupa denda, dan ada juga berupa penjara. Kedua, perbaikan dan pendidikan (al-islah wa al-tahdhib) yaitu agar mendidik pelaku jarimah menjadi orang baik dan menyadari atas kesalahan yang diperbuatnya, sehingganya diharapkan pelaku timbul kesadaran dan menjauhi jarimah tersebut bukan karena hukuman akan tetapi karena kesadaran diri pelaku guna mencapai ridha Allah subahanahu wataa'la. ${ }^{38}$

Mengutip pendapat Alyasa Abubakar menjelaskan bahwa para ulama menyimpulkan tujuan pemidanan dalam Al-qur'an atau tujuan hukuman cambuk yaitu : ${ }^{39}$

1. Pembalasan atas kejahatan atau perbuatan pidana yang dilakukan;

2. Memberikan efek jera, sehingga tidak mengulangi perbuatan pidana;

3. Mendidik dan memperbaiki pelaku perbuatan pidana;

4. Melindungi masyarakat.

Sehingga pelaksanaan uqubat cambuk merupakan kewenangan dan tanggungjawab Jaksa yang dilaksanakan setelah putusan hakim mempunyai kekuatan hukum tetap agar tercapai tujuan hukum diantaranya pembalasan atas kejahatan dan memberikan efek jera bagi pelaku. Namun, penundaan cambuk dapat dilakukan berdasarkan penetapan dari Kepala Kejaksaan Negeri Aceh Timur jika terdapat hal yang membahayakan terpidana dan setelah mendapat rekomendasi dari dokter.

Pelaksanaan uqubat cambuk dilaksanakan diatas alas berukuran minimal $3 \mathrm{x}$ 3 meter, jarak antara terpidana dengan pecambuk 0,07 meter sampai dengan 1 meter dengan posisi algojo atau pecambuk berdiri di sebelah kiri terhukum, pukulan tersebut diarahkan ke bagian punggung bahu sampai pinggu pelaku dan jarak antara tempat pelaksanaan dengan masyarakat yang melihat paling dekat 10 meter, dan rotan yang digunakan untuk memukul berdiameter 0,07 centimeter sampai 1 meter, dengan panjang rotan 1 meter dan tidak mempunyai ujung ganda. Sedangkan setelah dilakukan pengamatan di dalam Lembaga Permasyarakatan Kelas II B Idi bahwa Lapas Idi tidak memenuhi syarat untuk ukuran tersebut, sebagaimana dijelaskan Kepala Lapas Kelas II B Idi dalam wawancaranya. ${ }^{40}$ Sehingga penerapan Peraturan Gubernur Aceh Nomor 5 tahun 2018 oleh Jaksa pada Kejaksaan Negeri Aceh Timur hingga saat ini tidak dapat dilaksanakan.

\section{Hambatan Jaksa dalam melaksanakan Peraturan Gubernur Aceh Nomor 5 Tahun 2018 di Kabupaten Aceh Timur}

Kejaksaan Negeri Aceh Timur merupakan salah satu lembaga penegak hukum Syari'at Islam di Provinsi Aceh yang merupakan bagian dari Kejaksaan

\footnotetext{
${ }^{38}$, Abdul Gani Isa.,Ibid.,hlm. 416.

${ }^{39}$ Muslim Zainuddin, Loc.Cit,hlm.17.

${ }^{40}$ wawancara Eka Priyatna., Loc.Cit.
}

Suloh: Jurnal Fakultas Hukum Universitas Malikussaleh, Vol. 9, No. 1, April 2021, pp. 41 - 28 
Agung RI. Berbeda dengan kepolisian daerah di Provinsi Aceh tugas kepolisian diatur dalam Qanun, mengenai tugas Kejaksaan tidak diatur dalam qanun tersendiri, oleh karena itu Kejaksaan Negeri Aceh Timur mengacu kepada tugas dan wewenang yang tercantum di UU RI Nomor 16 Tahun 2004 tentang Kejaksaan RI serta Hukum Acara Jinayat.

Pengaturan tentang Kejaksaan diatur dalam UU RI Nomor 11 Tahun 2006 tentang Pemerintah Aceh, termuat dalam Bab XXVII mulai Pasal 208-210. Pasal 208 tentang Pemerintah Aceh dijelaskan bahwa Kejaksaan di Aceh merupakan bagian dari Kejaksaan Agung RI, serta Kejaksaan di Provinsi Aceh melaksanakan tugas dan kebijakan teknis di bidang penegakan hukum termasuk pelaksanaan syari'at Islam.

Pelaksanaan uqubat cambuk dimuka umum merupakan salah satu perwujudan dari adanya kepastian hukum yang bertujuan untuk meminta pertanggungjawaban bagi pelaku Jarimah, dan kepastian hukum akan diperoleh melalui proses hukum yang baik dan benar dengan mengacu pada ketentuan hukum yang berlaku, sehingga uqubat cambuk dapat memberikan kemanfaatan dalam kehidupan bermasyarakat dan memberikan keadilan bagi setiap manusia.

Keinginan Gubernur Aceh Irwandi Yusuf pada saat itu untuk memindahkan eksekusi cambuk dari tempat umum ke dalam penjara masih menghadapi hambatan baik sarana dan prasara maupun secara teknis, sehingga Peraturan Gubernur tersebut belum dapat dilaksanakan padahal peraturannya sudah ditandatangani sejak tahun 2018. Namun, hingga kini petunjuk teknis tentang bagaimana tata cara pelaksanaan cambuk di Lembaga Pemasyarakatan (penjara) belum ada. ${ }^{41}$

Gubernur Aceh Irwandi Yusuf pada Februari tahun 2018 telah mengeluarkan Peraturan Gubernur Nomor 5 tahun 2018 yang salah satu klausulnya mengatur tentang tempat uqubat cambuk dilaksakan. Selanjutnya dua bulan kemudian, Pemerintah Aceh juga telah menandatangani kerja sama dengan Kantor Wilayah Kementerian Hukum dan Hak Asasi Manusia (Kemenkumham) tentang pemindahan lokasi hukuman cambuk yang tadinya di tempat terbuka, kini dilakukan di penjara sesuai Nomor : 07/Pks/2018 dan Nomor:W1.107-Pk.01.06 tahun 2018. Tujuan pemindahan lokasi cambuk tersebut adalah untuk meredam timbulnya Islamophobia pihak luar atas pemberlakuan syariat Islam di Aceh, sehingga pelaksanaan hukuman ini tidak mengganggu urusan luar negeri dan menjaga agar anak-anak tak menyaksikan pelaksanaan hukuman cambuk. ${ }^{42}$

Namun, nyatanya terjadi hambatan teknis terkait pelaksanaan uqubat cambuk di penjara dialami berbagai pihak seperti wilayatul hisbah (WH) atau polisi syariah, Kejaksaan, Kepolisian, Mahkamah Syari'iyah, Dinas Syariat Islam, dan Kementerian Hukum dan HAM (Kemenkumham) sedang membahas peraturan turunan untuk mempermudah pelaksanaannya. Kepala Kemenkumham Aceh pada waktu itu Agus Toyib menyebutkan bahwa hanya ada 7 dari 23 penjara di Aceh yang layak digunakan sebagai lokasi eksekusi cambuk karena memiliki

\footnotetext{
${ }^{41}$ Beritabenar,https://www.benarnews.org/indonesian/berita/hukum-cambuk-aceh-penjara02082019150603.html, diunduh 27 Maret 2020.

42 Ibid, Berita benar.
}

Suloh: Jurnal Fakultas Hukum Universitas Malikussaleh, Vol. 9, No. 1, April 2021, pp. 42 - 28 
lapangan, sedangkan Rutan Cabang langsa di Idi yang sekarang menjadi Lembaga Permasyarakatan Kelas II B Idi tidak termasuk dari 7 penjara dimaksud. ${ }^{43}$

Menurut Kamus Besar Bahasa Indonsia (KBBI) pengertian hambatan adalah sebuah halangan rintangan, atau penghalang. Kaitannya dalam penerapan Peraturan Gubernur Aceh Nomor 5 tahun 2018 oleh Jaksa menurut Soerjono Soekanto bahwa terdapat beberapa faktor yang mempengaruhi penegakan hukum dalam pelaksanannya diantaranya ${ }^{44}$ faktor hukumnya yaitu undangundang/peraturan dan sebagainya, faktor sarana atau fasilitas yang mendukung penegakan hukum dalam permasalahan ini mengenai kondisi dalam Lembaga Permasyarakatan Kelas II B Idi, dan faktor masyarakat yaitu lingkungan dimana hukum tersebut berlaku atau diterapkan yaitu di Kabupaten Aceh Timur.

Adapun kendala yang dihadapi Jaksa Peuntut Umum dalam melaksanakan Peraturan Gubernur Nomor 5 tahun 2018 tersebut bervariatif yaitu Lembaga Permasyarakatan Kelas II B Idi tidak memenuhi syarat tentang jarak lokasi pelaksanan cambuk, tempat tidak memadai, serta belum adanya aturan pelaksanaannya seperti Petunjuk Teknis atau Petunjuk Pelaksanaan dari pimpinan di Kejaksaan Tinggi Aceh mengenai pelaksanaan cambuk di dalam Lembaga Permasyarakatan Kelas II B Idi. ${ }^{45}$

Selain itu, hambatan laiinya yaitu belum ada petunjuk teknis dan petunjuk pelaksanaan cambuk di dalam Lapas Kelas II B Idi, kurangnya anggaran yang disediakan Pemerintah Kabupaten, dan keterbatasan tempat di Lapas karena terdapat syarat lain seperti jarak pelaksanaan cambuk harus 12 meter dari panggung eksekusi, ${ }^{46}$ dan mengenai anggaran eksekusi cambuk untuk saat ini sudah beralih ke Satuan Polisi Pamong Praja dan Wilayatul Hisbah Kabupaten Aceh Timur, yang sebelumnya pada tahun 2018 diketahui terdapat alokasi anggaran sebesar Rp.34.000.000. ${ }^{47}$

Berikut hambatan yang di temui dan dihadapi oleh Jaksa dalam menerapkan Peraturan Gubernur 5 tahun 2018 jika dilaksanakan di dalam Lapas Kelas II B Idi, yaitu:

${ }^{43}$ Ibid, Berita benar.

44 Abdul Gani Isa, Formalisasi Syari'at Islam di Aceh (Pendekatan Adat, Budaya, dan Hukum), Aceh: Yayasan Pena Banda Aceh, Cet-I, 2013, hlm. 265.

${ }^{45}$ Wawancara Abun Hasbulloh Syambas, Kepala Kejaksaan Negeri Aceh Timur, Selasa, 03 Maret 2020, 09.00-10.00 Wib, Ruang Kepala Kajaksaan Negeri Aceh Timur.

46 Wawancara T. Swandi, Hakim Mahkamah Syari'yah Idi, Kamis, 27 Februari 2020, 10.30-11.30 wib, Ruang Hakim Mahkamah Syari’yah Idi.

${ }^{47}$ Wawancara Rusydi, Kepala Dinas Syariat Islam Kab. Aceh Timur, Kamis, 27 Februari 2020, 14.00-15.00 wib, Ruang Kepala Dinas Syariat Islam Kab. Aceh Timur.

Suloh: Jurnal Fakultas Hukum Universitas Malikussaleh, Vol. 9, No. 1, April 2021, pp. 43 - 28 


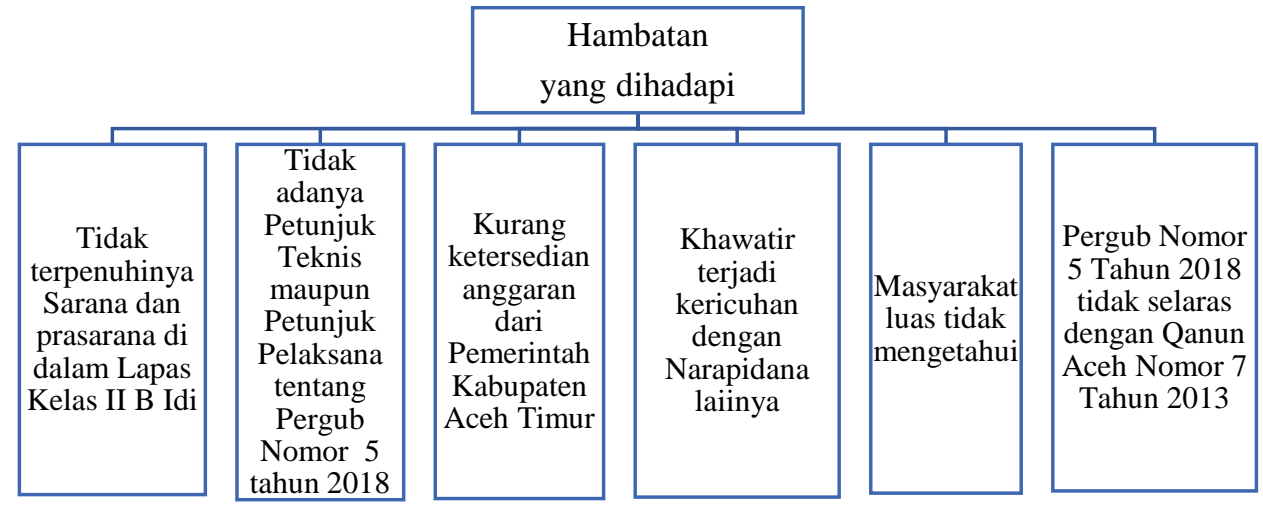

Hal senada juga disampaikan oleh Kepala Lapas Kelas II B Idi hambatan yang terjadi dikarenakan tidak tersedianya sarana dan prasarana, keterbatas tempat pelaksanan cambuk mengenai ketentuan jarak dan ukuran panggung eksekusinya, dikhawatirkan apabila dilaksanakan di dalam Lapas akan timbul keributan dari para warga binaan (narapidana), dan apabila eksekusi cambuk dilaksanakan di dalam Lapas Kelas II B Idi maka masyarakat pada umumnya tidak mengetahuinya atau tidak dapat melihat secara langsung, karena tujuan utama dari eksekusi cambuk adalah untuk memberikan efek malu bagi pelaku. ${ }^{48}$

Efek malu yang ditimbulkan akibat pelaksanaan eksekusi cambuk selaras pendapat Jeremy Bentham dengan teori utilitasnya bahwa hukum bertujuan memberikan manfaat bagi manusia, hal ini menitikberatkan pada hal-hal yang bermanfaat bagi orang banyak dan bersifat umum, sehingga manfaat yang akan dicapai dari cambuk adalah memberikan contoh kepada masyarakat luas. Kendala laiinya yang masih dihadapai dalam melaksanakan Syari'at Islam atau penegakan hukum Jinayat di Aceh menurut Muslim Ibrahim yaitu: ${ }^{49}$

1. Kultural atau sosiologi adanya umat Islam di Provinsi Aceh yang masih belum bisa menerima pelaksanaan syari'at Islam;

2. Fikrah (pemikiran) adalah masih banyaknya pandangan negatif terhadap hukum pidana Islam dan kurang yakin dengan efektivitasnya;

3. Filosofis berupa tuduhan bahwa hukum ini tidak adil (kejam dan ketinggalan zaman) bahkan bertentangan dengan cita-cita hukum nasional.

4. Yuridis yang tercermin dari belum adanya ketentuan hukum pidana yang bersumber dari syari'at Islam;

5. Kendala konsolidasi umat yang terwujud pada belum bisa bertemunya para pendukung pemberlakuan syari'at Islam (dari berbagai kalangan) yang masih saling menonjolkan pendapat serta metode penerapannya masingmasing;

6. Akademis terlihat dari belum meluasnya pengajaran hukum pidana Islam ini di sekolah atau perguruan tinggi

${ }^{48}$ Wawancara Eka Priyatna, Kepala lapas Kelas II B Idi, Selasa, 25 Februari 2020, 10.3011.30 Wib, Ruang Kalapas Kelas II B Idi.

${ }^{49}$ Dede Hendra Mr, Tesis Eksistensi Penerapan Pidana Cambuk Terhadap Pelanggar Qanun Syariat Islam di Provinsi Aceh, Disertasi Program Pascasarjana Fakultas Hukum Universitas Indonesia, Jakarta 2012, hlm.117.

Suloh: Jurnal Fakultas Hukum Universitas Malikussaleh, Vol. 9, No. 1, April 2021, pp. 44 - 28 
7. Perumusan yang terlihat dari belum adanya upaya yang sistem matis untuk merumuskan hukum pidana yang sesuai syari'at Islam sebagai persiapan mengganti hukum pidana barat;

8. Struktural yang terlihat dari belum adanya struktur hukum yang dapat mendukung penerapan syari'at Islam;

9. Ilmiah tercermin dari kurang banyaknya literatur ilmiah yang mengulas hukum pidana Islam, dan;

10. Politis terlihat dari masih kurang cukupnya kekuatan politik untuk menggolkan penegakan syari'at Islam melalui proses-proses politik.

Proses penegakan hukum yang dialamai oleh Jaksa mengutip pendapat Soerjono Soekanto terdapat beberapa faktor yang mempengaruhi proses penegakan hukum yaitu faktor hukumnya dalam hal ini Peraturan Gubernur Nomor 5 tahun 2018 itu sendiri, faktor penegak hukum yaitu pihak yang membentuk maupun yang menerapkan dalam hal ini Jaksa, faktor sarana atau fasilitas yang mendukung penegakan hukum yang berada dalam Lapas Kelas II B Idi, dan faktor masyarakat yaitu lingkungan dimana hukum tersebut berlaku atau diterapkan di Kabupaten Aceh Timur ${ }^{50}$ sehingga beberapa alasan tersebut diatas menjadi kendala dalam penerapan hukuman terhadap pelaku pelanggar syari'at Islam.

Mengutip pendapat Aberr Bashier Dababneh dan Eid Ahmad Al Husban mengatakan bahwa suatu undang-undang dianggap baik jika proses pembentukannya memperhatikan dan mempedomani prinsip-prinsip berikut ${ }^{51}$ undang-undang harus masuk akal sehingga orang awam dengan mudah mempelajarinya, undang-undang harus sederhana untuk mencapai tujuan menyelesaikan konflik, undang-undang harus memiliki kestabilan legislatif sehingga orang tidak melanggarnya, undang-undang harus ditandai dengan harmonisasi berbagai undang-undang sehingga tidak ada pertentangan,undangundang harus mencerminkan realitas masyarakat, undang-undang harus sesuai dengan aturan hukum yang lebih tinggi (prinsip hierarki), sehingga seyogyanya dalam pembentukan Peraturan Gubernur Aceh Nomor 5 Tahun 2018 dapat mempedomi prinsip tersebut.

Pasal 262 Qanun Aceh Nomor 7 Tahun 2013 tentang Hukum Acara Jinayat menjelaskan bahwa uqubat cambuk dilaksanakan di suatu tempat terbuka dan dapat dilihat oleh orang yang hadir, dan pelaksanaan uqubat cambuk dilaksanakan di atas alas (bidang) berukuran minimal 3 x 3 meter, dengan Jarak antara tempat berdiri terhukum dengan masyarakat penyaksi paling dekat 12 meter, sehingga dalam pelaksanaannya Jaksa Penuntut Umum tidak dapat melaksanakan eksekusi tersebut di dalam Lapas Kelas II B Idi karena syarat yang ditentukan tidak dapat diterapkan.

Sementara, berdasarkan Pasal 30 Peraturan Gubernur Aceh Nomor 5 Tahun 2018, menjelaskan bahwa pelaksanan Uqubat cambuk dilaksanakan disuatu tempat terbuka dan dapat dilihat oleh orang yang hadir, dan tempat terbuka

50 Titik Triwulan Tutik, Pengantar Hukum Tata Usaha Negara Indonesia, Jakarta : Prestasi Pustaka, Cet-I, 2010, hlm. 265.

${ }^{51}$ Putera Astomo, Ilmu Perundang-undangan Teori dan Praktik di Indonesia, Depok: PT. Raja Grafindo Persada, Cet-I, 2018,hlm.91.

Suloh: Jurnal Fakultas Hukum Universitas Malikussaleh, Vol. 9, No. 1, April 2021, pp. 45 - 28 
sebagaimana dimaksud yaitu bertempat di Lembaga Permasyarakatan atau Rumah Tahanan atau Cabang Rumah Tahanan, dan Pelaksanaan Uqubat cambuk di Lembaga Permasyarakatan atau Rumah Tahanan atau Cabang Rumah Tahanan dilaksanakan setelah adanya naskah kerjasama antara Pemerintah Aceh dengan Kantor Wilayah Kementerian Hukum dan Hak Azasi Manusia RI, sedangkan hingga kini petunjuk teknis maupun petunjuk pelaksanaan tersebut belum ada. ${ }^{52}$

Meskipun Gubernur Aceh Irwandi Yusuf telah melakukan Perjanjian Kerjasama antar Pemerintah Aceh dengan Kantor Kementerian Hukum dan Hak Azasi Manusia Aceh tentang Pelaksanaan Peraturan Gubernur Aceh Nomor 5 tahun 2018 tentang pelaksanaan Hukum Acara Jinayat Nomor : 07/Pks/2018 dan Nomor : W1.107-Pk.01.06 tahun 2018 tersebut, namun dalam penerapannya belum dapat terlaksana di Lapas Kelas II B Idi.

Pelaksanan uqubat cambuk seharusnya segera dilaksanakan setelah adanya putusan Mahkamah Syariah yang telah memperoleh kekuatan hukum tetap sesuai pasal 247 ayat 2 Qanun Aceh No. 7 tahun 2013, dan telah diterimanya salinan putusan oleh Jaksa Penuntut Umum, namun sekali lagi dalam pelaksanaannya terbentur dengan tidak tersedianya anggaran, padahal berdasarkan Pasal 284 Qanun Aceh No. 7 tahun 2013 tentang Hukum Acara Jinayat menyebutkan bahwa Pemerintahan Kabupaten/kota berdasarkan Pasal 127 ayat (3) UU RI No. 11 Tahun 2006 tentang Pemerintahan Aceh mengalokasikan dana dan sumber daya lainnya untuk pelaksanaan Hukum Acara Jinayat. ${ }^{53}$

Dengan tidak adanya anggaran untuk pelaksanaan Uqubat cambuk di Kabupaten Aceh Timur, maka Jaksa Penuntut Umum pada Kejaksaan Negeri Aceh Timur dalam Surat Tuntutan terhadap pelaku Jarimah menuntut pelaku dengan Uqubat penjara di Rutan Cab. Langsa di Idi yang sekarang berubah nama menjadi Lapas Kelas II B Idi, ${ }^{54}$ hal ini untuk mewujudkan cita hukum secara proporsional, yaitu kepastian hukum (rechtssicherkeit), keadilan (gerechtigkeit) dan kemanfaatan (zweckmasigkeit).

Oleh karena itu, hambatan yang terjadi tersebut seyogyanya ditinjau kembali oleh pihak terkait baik dari segi peraturan pelaksana, sarana dan prasarana, anggaran eksekusi cambuk, dan sosial masyarakat, sehingga terhadap keseluruhan dari Peraturan Gubernur Aceh Nomor 5 Tahun 2018 Tentang Pelaksanan Hukum Acara Jinayat dapat dilaksanakan oleh Jaksa serta selaras dengan Qanun Aceh Nomor 7 Tahun 2013 Tentang Hukum Acara Jinayat.

\section{Kesimpulan}

1. Pelaksanaan Peraturan Gubernur Nomor 5 tahun 2018 yang dilakukan oleh Jaksa Penuntut Umum pada Kejaksaan Negeri Aceh Timur terhadap pelaku Jarimah hingga saat ini tidak dapat dilaksanakan di dalam Lapas Kelas II B Idi, sehingga dalam melaksanakan uqubat cambuk Jaksa Penuntut Umum berpedoman pada Pasal 262 Qanun Aceh Nomor 7 Tahun 2013 tentang

${ }^{52}$ Wawancara Eka Priyatna, Kepala lapas Kelas II B Idi, Selasa, 25 Februari 2020, 10.3011.30 Wib, Ruang Kalapas Kelas II B Idi

${ }^{53}$ Wawancara Teuku. Amran, Kasat Pol PP dan WH Kab. Aceh Timur, dan Wawancara Rusydi, Kepala Dinas Syariat Islam Kab. Aceh Timur.

${ }^{54}$ Wawancara Eka Priyatna, Kepala lapas Kelas II B Idi.

Suloh: Jurnal Fakultas Hukum Universitas Malikussaleh, Vol. 9, No. 1, April 2021, pp. 46 - 28 
Hukum Acara Jinayat yang menjelaskan bahwa uqubat cambuk dilaksanakan di suatu tempat terbuka, dan tempat terbuka yang dimaksud yaitu di lingkungan Masjid Agung Darushalihin Idi Rayeuk.

2. Bahwa hambatan yang ditemui dan dihadapi oleh Jaksa Penuntut Umum dalam melaksanakan Peraturan Gubernur Nomor 5 tahun 2018 tersebut bagi pelaku jarimah diantara lain tidak adanya sarana dan prasarana yang memadai di lapas Kelas II B Idi sesuai syarat yang ditentukan dalam pasal 262 Qanun Nomor 7 tahun 2013, belum terdapatnya Petunjuk Teknis dan Petunjuk Pelaksana terkait Peraturan Gubernur Nomor 5 tahun 2018 tersebut dari Kejaksaan Tinggi Aceh maupun di Lingkungan Kemkumhan Lapas Kelas II B Idi, ketersediaan anggaran uqubat cambuk yang terbatas dari Pemerintah Kabupaten Aceh Timur, dan dikhawatirkan akan timbul keributan dari para warga binaan (narapidana) di dalam Lapas, serta masyarakat pada umumnya tidak mengetahui eksekusi cambuk tersebut.

\section{Daftar Pustaka}

\section{A. Buku}

Abdul Gani Isa, Formalisasi Syari'at Islam di Aceh (Pendekatan Adat, Budaya, dan Hukum), Aceh: Yayasan Pena Banda Aceh, Cet-I, 2013.

Amiruddin, Zainal Asikin, Pengantar Metode Penelitian Hukum, Jakarta: PT. Raja Grafindo Persada, Cet-I, 2004.

Busthanul Arifin, Pelembagaan Hukum Islam di Indonesia Akar Sejarah, Hambatan, dan Prospeknya, Jakarta; Gema Insani Press, Cet ke-I, 1996.

Marwan Effendy, Teori Hukum dari perspektif kebijakan, perbandingan, dan harmonisasi hukum pidana, Ciputat: Referensi (Gaung Persada Press Group), Cet ke-I, 2014.

Mukti Fajar dan Yulianto Achmad, Dualisme Penelitian Hukum Normatif dan Empiris, Yogyakarta: Pustaka Pelajar, 2010.

Muslim Zainuddin, Problematika hukuman cambuk di Aceh, Aceh: Dinas Syariat Islam Aceh, Edisi Pertama, 2011.

Putera Astomo, Ilmu Perundang-undangan Teori dan Praktik di Indonesia, Depok: PT. Raja Grafindo Persada, Cet-I, 2018.

Riduan Syarani, Rangkuman Instisari Ilmu Hukum, Bandung: Citra Aditya Bakti, 2004.

Sadjijono, Hukum Antara Sollen Dan Sein Dalam Perspektif Praktek Hukum di Indonesia, Surabaya: Ubhara Press dan Laksbang Pressindo, Cet keII. 2017.

Titik Triwulan Tutik, Pengantar Hukum Tata Usaha Negara Indonesia, Jakarta : Prestasi Pustaka, Cet-I, 2010.

Zainuddin Ali, Metode Penelitian Hukum, Jakarta : Sinar Grafika, Cet. ke-8, 2016. 
Zulkarnaen, Beni Ahmad Saebani, Hukum Konstitusi, Bandung: CV. Pustaka Setia, Cet. Pertama, 2012.

\section{B. Tesis / Disertasi}

Dede Hendra Mr, "Tesis Eksistensi Penerapan Pidana Cambuk Terhadap Pelanggar Qanun Syariat Islam di Provinsi Aceh”, Disertasi Program Pascasarjana Fakultas Hukum Universitas Indonesia, Jakarta 2012.

Delfi Suganda, "Pancasila dan Syari'at Islam sebagai Asas-Asas Pembentukan Qanun di Nanggroe Aceh Darussalam (Studi Kasus Peraturan Daerah No. 5 Tahun 2000 Tentang Pelaksanaan Syariat Islam)", Disertasi Program Pascasarjana Fakultas Hukum Universitas Gajah Mada, Yogjakarta 2012.

Khairil Akbar, "Relevansi Prinsip Pemidanaan Islam Terhadap Sila Ketuhanan Yang Maha Esa (Studi Terhadap Qanun Aceh Nomor 6 Tahun 2014 Tentang Hukum Jinayat)", Disertasi Program Pascasarjana Fakultas Hukum Universitas Islam Indonesia, Jogjakarta, 2017.

\section{Jurnal / Artikel}

Muhammad Hilmi Akhsin, Anis Mashdurohatun, Akibat Hukum Jaminan Fidusia Yang Tidak Didaftarkan Menurut UU No. 42 Tahun 1999, Jurnal Akta, Vol.4 No. 3, 2017.

Natangsa Surbakti, Problematika Penegakan Hukum Undang-Undang Penghapusan Kekerasan Dalam Rumah Tangga, Jurnal Ilmu Hukum, Vol. 9, No. 1, Maret 2006.

\section{Internet}

Antaraaceh, https://aceh.antaranews.com/berita/122966/tiga-terpidana-maisirdihukum-cambuk-di-aceh-timur, diunduh tanggal 30 Mei 2020.

Berita Resmi Pemerintah Provinsi Aceh Biro Humas dan Protokol Sekretarian Provinsi Aceh https://humas.acehprov.go.id/penjelasan-gubernurterhadap-hak-interpelasi-dpra/diunduh 16 November 2019.

Modus Aceh https://modusaceh.co/news/ini-poin-perjanjian-pemerintah-acehdan-kemenkumham-aceh/index.html diunduh 16 November 2019.

\section{E. Peraturan Perundang-undangan}

Undang-undang RI Nomor 44 tahun 1999 tentang Penyelenggaraan Keistimewaan Provinsi Aceh (Lembaran Negara RI tahun 1999 Nomor 172)

Undang-undang RI Nomor 18 Tahun 2001 tentang Otonomi Khusus Bagi Provinsi Daerah Istimewa Aceh Sebagai Provinsi Nanggroe Aceh Darussalam. (Lembaran Negara RI tahun 2001 Nomor 114) 
Undang-undang RI Nomor 16 Tahun 2004 Tentang Kejaksaan RI (Lembaran Negara RI tahun 2004 Nomor 67)

Undang-undang RI Nomor 11 Tahun 2006 tentang Pemerintahan Aceh (Lembaran Negara RI tahun 2006 Nomor 62)

Undang-undang RI Nomor 12 Tahun 2011 Tentang Pembentukan Peraturan Perundang-undangan (Lembaran Negara RI tahun 2011 Nomor 82)

Qanun Aceh Nomor 7 Tahun 2013 Tentang Hukum Acara Jinayat (Lembaran Aceh tahun 2013 Nomor 7)

Qanun Aceh Nomor 6 Tahun 2014 Tentang Hukum Jinayat (Lembaran Aceh tahun 2014 Nomor 7)

Peraturan Gubernur Aceh Nomor 10 Tahun 2005 Tentang Petunjuk Teknis Pelaksanan Hukuman Cambuk (Lembaran Aceh tahun 2005 Nomor 06)

Peraturan Gubernur Aceh Nomor 5 tahun 2018 Tentang Pelaksanaan Hukum Acara Jinayat. (Berita Daerah Aceh tahun 2018 Nomor 5) 